\title{
THE EFFECTS OF FLIPPED CLASSROOM INSTRUCTIONS ON STUDENT'S MOTIVATION IN ALGEBRAIC COMPONENT
}

\author{
${ }^{1}$ Mohd Zamri Abdullah, ${ }^{2}$ Mustafa Mamat \\ 1.Institut Pendidikan Guru Kampus Kota Bharu \\ ${ }^{2}$ Universiti Sultan Zainal Abidin \\ *email : zamriabdullah70@gmail.com
}

Received : 17 Mei 2018; Accepted : 03 July 2018; Published : 23 December 2018

\begin{abstract}
The Ministry of Education Malaysia (MoE) has suggested using Flipped Classroom (FC) teaching method as an innovation in the teaching of additional mathematics especially in algebra. The suggestion of using FC is very much related to the concept of $21^{\text {th }}$ Century Classroom that emphasizes good communication, collaboration, critical as well as creative thinking. This quasi-experimental research was carried out to determine the effects of FC on the motivation of students taking additional mathematics. Treatment group $(\mathrm{n}=36)$ was treated with FC methods, whereas control group $(\mathrm{n}=$ 34) received conventional methods of learning additional mathematics. To control the difference in dependent variables, a pre-test was given before the experiment started. After nine weeks of treatment, both groups were given a post-test. The motivational questionaire on additional mathematics was used as a tool to collect the data. In determining the difference of data between treatment and control groups, the pre- and post tests data were analyzed using multivariate analysis of variance (MANOVA) followed by univariate analysis of variance (ANOVA). The findings from ANOVA analysis reveal that overall there was a difference between the treatment and control groups for motivation. MANOVA analysis confirms more significant differences on motivational subscales namely on attention, relevance, level of confidence and satisfaction between these two groups. In general, the impact was very substantial and gave a strong indication that the treatment was very meaningful. Therefore, this research has given a new and ideal way of teaching additional mathematics to school administrators, subject teachers and students by engaging the use of alternative dynamic geometric softwares that are of the same quality as the ones supplied by MoE.
\end{abstract}

Keywords Flipped Classroom, Algebraic, Motivation.

\begin{abstract}
Abstrak
Kaedah pembelajaran Flipped Classroom (FC) merupakan satu inovasi terhadap proses pengajaran dan pembelajaran Matematik
\end{abstract}


Tambahan terutama bagi tajuk algebra seperti yang disarankan oleh Kementerian Pelajaran Malaysia (KPM). Kaedah pembelajaran ini bertepatan dengan kaedah pembelajaran abad ke-21 yang menekankan terhadap komunikasi, kolaborasi, pemikiran kritikal dan juga kreativiti. Sehubungan dengan itu kesan eksperimental kuasai ini dilakukan bagi menentukan kesan pembelajaran Flipped Classroom ke atas motivasi pelajar terhadap subjek Matematik Tambahan. Kumpulan rawatan $(\mathrm{n}=36)$ adalah kumpulan pembelajaran $\mathrm{FC}$, manakala kumpulan kawalan $(n=34)$ menerima pembelajaran secara konvesional. Bagi mengawal perbezaan pemboleh ubah-pemboleh ubah bersandar, ujian pra diberikan sebelum kajian ini dilakukan. Selepas 9 minggu rawatan, kedua-dua kumpulan diberikan ujian pos. Alat kajian digunakan bagi mendapatkan data iaitu soal selidik motivasi terhadap Matematik Tambahan. Bagi menentukan perbezaan antara kumpulan rawatan dan kumpulan kawalan, data ujian pra dan ujian pos dianalisis dengan menggunakan analisis varian multivariat (MANOVA), diikuti dengan analisis varian univariat (ANOVA). Dapatan kajian daripada analisis ANOVA menunjukkan terdapat perbezaan secara keseluruhan antara kumpulan FC dan kumpulan konvesional bagi motivasi, Analisis MANOVA menunjukkan terdapat perbezaan yang signifikan terhadap subskala motivasi iaitu perhatian, relevan, keyakinan dan kepuasan bagi kumpulan FC dan konvesional. Secara keseluruhan, saiz kesan adalah besar dan membawa implikasi terdapat kesan rawatan yang bermakna. Kajian ini telah memberi cetusan idea kepada pihak pentadbiran sekolah, guru dan pelajar bagi mendapatkan sumber alternatif perisian geometri dinamik yang berkualiti standing dengan perisian yang dibekalkan oleh Kementerian Pelajaran Malaysia.

Kata kunci Flipped Classroom, Algebra, Motivasi.

\section{INTRODUCTION}

Flipped Classroom (FC) is a 21 st century learning model based on multi-mode learning (Jensen et al., 2015). Multi-mode learning or « Blended Learning" refers to the integration of face-to-face teaching approaches and technology-assisted teaching approaches to support the teaching and learning of Science, Technology, Engineering and Mathematics (STEM) (Ministry of Education Malaysia, 2013). According to Constructivist Theory by Jean Piaget (1952) and Vygotsky (1987), students need to self-explore and do self-directed learning actively to build self-esteem, to collaborate with others for social support (scaffolding) or do online education programs to assist in effective learning as well as to build higher order thinking skills (HOTS) within themselves (Abeysekera \& Dawson, 2015).

The Flipped Classroom model was first introduced in 2000 (Baker, 2000) and is also known as "inverted classroom" (Lage et al., 2000). Flipped Classroom became 
popular after being propagated by two school teachers, Bergmann and Samms (2009) through the use of video and online learning activities. The advantage of Flipped Classroom is that it has two phases of learning. The first phase is by giving students the opportunity to study independently and in the second phase the students learn to build knowledge through experience or through the guidance of teachers and friends (Lowell et al., 2013). Consequently, the FC method can help create an active learning environment (Siegle, 2013). Through active learning, according to Cano et al. (2013) students will be encouraged to learn independently through project-based learning (PBL) besides learning interactively and cooperatively with peers improving their spirit of competitiveness. This will increase students' motivation and also reduce stress and negative feelings towards the lessons learned (Strayer, 2012; Acar et al., 2015).

The introduction of FC model as 21 st century pedagogy is in line with the development of information technology among generations ' $Y$ ' and ' $Z$ ' (Bernard, 2015). Shahanim (2012) states that ' $Z$ ' generation differs with ' $Y$ ' in terms of communication and how it works. Generation $Y$ focuses more on formal learning that is seen to contribute skills and expertise in career, while ' $Z$ ' generation is more likely to be virtual, practical and to build expertise rather than «test and try". Generation ' $Z$ ' is a generation that was born after 1990, the time when technology has started to dominate the world. Generation ' $Z$ ' is known as a silent genus and the generation of the internet and is in the virtual world. They are very much connected with lots of people from all over the internet (Paul, 2013). However, they are somewhat weak in terms of expression, oral communication, confidence and interpersonal skills (Lancaster \& Stillman, 2003). Today, 'Z' generation constitutes nearly 18 percent of the population of the world. For $Z$ generation gene, computer technology and internet are common place. All their communications take place on the internet and they demonstrate very little verbal communication skills. Most of their lives are spent browsing he "World Wide Web" (www). They are accustomed to immediate action and satisfaction through internet technology (Paul, 2013).

Based on the statistics released by the Ministry of Education (MoE) from 1981 to 2010 , the percentage of secondary school students joining in the science stream has never reached the $60: 40$ ratio as outlined in item 4.9 in the National Education Policy setting (Fatin et al., 2014). Figure 1 shows the number of students joining the science stream in the year 2005 as only 31.22 percent. However, the percentage of students in the arts stream remained above other streams throughout 1981-2010. The Ministry of Education Malaysia (2013), also reports a decrease in the percentage of students choosing the STEM field in the upper secondary, higher education institutions and other institutions of higher learning in the country. The effect is evident in 2011 when only $45 \%$ of students were successful in their pursuit of pure science, technical and vocational programs (KPM, 2013).

Various views have been raised to explain the phenomenon of students' lack of interest in science. Students argue that science, mathematics, engineering and mathematics (STEM) subjects such as additional mathematics are not only boring but too abstract and then there is a notion that taking STEM related courses does not lead to lucrative jobs and income (Ayob, 2012). In summary, the perceptions 
shown by the students on STEM subjects are negative and they are less motivated in the subject. Various efforts have been made by the responsible party to counteract the negative attitude towards STEM and to increase the number of students in the stream (Ayob, 2012). A study by Fatin et al. (2014), has concluded that the decline in the participation of secondary school students in STEM is due to the following factors: students' lack of motivation and interest in subjects, poor teaching methods and weak metacognition awareness among students on high order thinking skill (HOTS) questions.

In the Additional Mathematics syllabus, topics like algebraic equations and quadratic functions are important in school mathematics curriculum as they relate to symbols, graphs, functions and arithmetic calculations. Without an understanding of symbols, graphs of functions and arithmetic calculations, algebraic learning at the secondary level will be difficult (Mc Givney Burelle \& Xue, 2013). Lima and Tall (2006) claim that algebraic teaching and learning is difficult. Furthermore, the use of unknown in algebra confuses students. In addition, pupils face problems in terms of language difficulty in learning symbols, notations and mathematical terms. Katz \& Barton (2007) express the difficulty of students understanding algebra: -

" Algebra is a general method of computation by certain signs and symbols which have been contrived for this purpose, and found convenient. It is called a universal arithmetic, and proceeds by operations and rules similar to those in common arithmetic, founded upon the same principles.

(Katz \& Barton, 2007, p. 185).

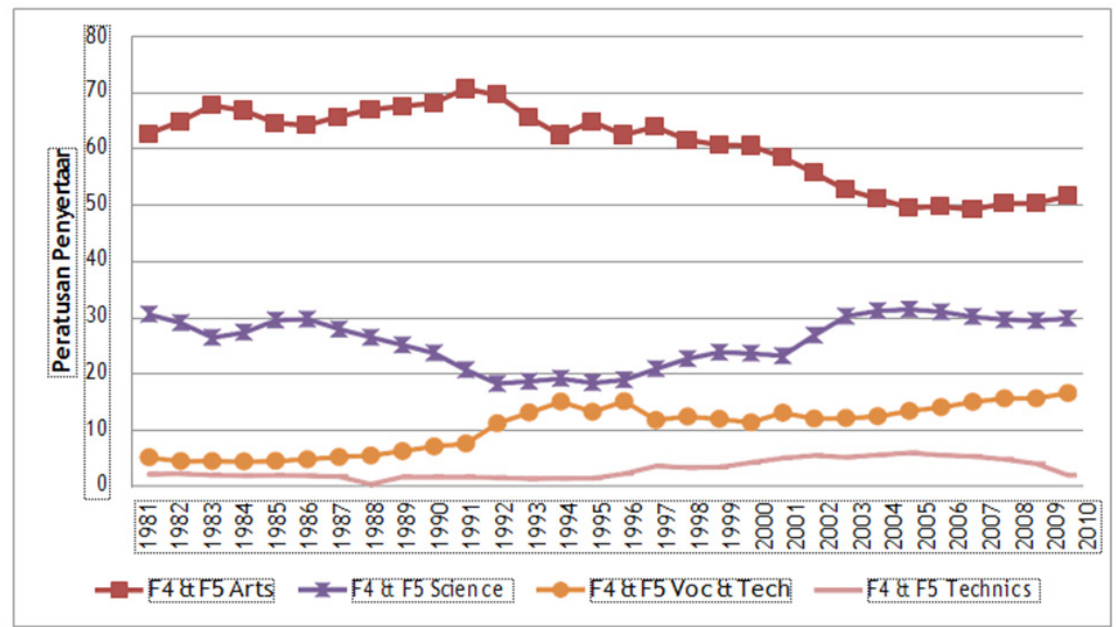

Figure 1 Percentage of students by streams from 1981 to 2010

The difficulty of students in the country to master the algebraic skills of the additional mathematics can be seen in the report of the Malaysian Examination Board (LPM, 2016). According to this report, the overall achievement of the candidates for additional mathematics is moderate. In the 2015 Sijil Pelajaran Malaysia (SPM) report for Additional Mathematics paper 1, the candidates were required to master the 
factoring skills and the development of algebraic expressions well and understand the graph of quadratic function. This report explains the importance of good mastery over the concept of algebra, in particular for the topics quadratic equation and quadratic function. According to Mazur et al., (2015), these topics need clear understanding of the concept as they are interconnected and have links to the following topics such as linear programming, coordinate geometry and linear law. Students need a good understanding of concepts to make the right interpretation of questions with HOTS.

Past studies revealed that most students found it difficult to retain the memory of a function graph image when there is an addition or multiplication with a constant like in the quadratic function. For example, understanding how the function graph $y$ $=x^{2}$ changes when added to $y=x^{2}+3$ or $y=5 x^{2}+1$, drawing a graph to find the maximum and minimum points, determining the cause of the quadratic equation and also solving that particular problem. This is because algebra requires students to explore, explain patterns and relationships in tables such as by inserting algebraic symbols and manipulating graphic images. To enhance the effectiveness of teaching and learning of this topic, researchers are of the opinion that a method of teaching and learning using various medium needs to be established and FC fits this need very well. The FC learning model refers to the integration of face-to-face teaching approaches and technology-assisted teaching approaches in support of algebraic understanding (O>Flaherty \& Phillips, 2015).

\section{LITERATURE REVIEW}

Keller (1987) has produced a model on motivation called the ARCS model based on the theory of 'Vroom's expectancy-value theory' (Bixler, 2000). According to Knowles (1984), motivating students through the use of interactive modules is an important thing during the learning process as students are more interested in learning things that are directly related to their work and life. Motivating students will have a positive impact on conceptual understanding and student achievement on subjects learned. Alessi and Trollip (2001) think Keller $>$ s views are generally related to the suggestion that the builder of instructions must also be skillful in motivating students other than having the mastery in teaching and designing of games. Keller identified four factors to increase the motivation to learn, namely: attracting attention, relevance, confidence and satisfaction. Keller also produced an «Instructional Materials Motivation Survey' (IMMS) forms based on the ARCS model. Keller refers attention to how teaching materials such as dynamic software can attract students' attention when using them (Keller, 1987).

The intrinsic and extrinsic motivation of the students will grow if they feel that the learning materials used can be applied in real life, beneficial and of credible value (Keller, 1987; Song, 1989; Gabrielle, 2003). In order to generate confidence in the teaching and learning process, students need to be exposed to active learning situations through the use of stimulating teaching materials towards self-directed learning (Keller, 1987). The use of interactive learning materials is an ideal learning tool to give students confidence during their involvement in planned learning 
situations so they can hone their problem-solving skills. Confidence in learning situations affects self-esteem and will motivate students (Keller, 1987). Satisfaction refers to the joy and happiness of the students when they use FC during their learning activity (Huang et al., 2016). The use of online learning allows students to have fun and be happy during learning sessions. This feeling will increase the level of self motivation of the students. Past literature shows there is a significant relationship between motivation and the use of FC during teaching and learning sessions. Šlaus and Jacobs (2011) define motivation as the power that can encourage students in the positive direction to achieve learning objectives. Students> motivation is also seen as a drive, an effort and a willingness to participate in learning something that the teacher delivers. In education, the element of motivation is important in providing the support towards achievement as well as the ability to master the subjects learned.

Based on self-efficacy theory, student motivation can be divided into two, namely intrinsic motivation and extrinsic motivation (Abeysekera and Dawson, 2015). The intrinsic motivation is active internal stimuli that function without the need to be stimulated externally because the individual has the internal urge to do something. As an example, someone who likes to read does not need anyone to tell or encourage him to read because he is diligently looking for books to read. On the other hand, extrinsic motivation, though also an active motivation, only functions due to external stimuli. For instance, one learns diligently because one wants to be complimented by their colleagues for achievement in the test. Therefore, based on the analysis and interpretations of motivation, FC learning strategies should promote behavior change through self-learning and this would enable them to weather the learning situations online as well as face to face. Such learning activities will stimulate student motivation through the freedom of learning time and support of facilitators and peers to solve learning problems (Presti, 2016). Davies et al. ,(2013) finds that confident students are not bound by instructions to learn but have high motivation to achieve learning outcomes. They also suggest this learning strategy to their peers. The FC method also encourages students to be independent without having any feeling of inferiority complex. When learning online, students are free to give their opinions while interacting with the virtual world. This is completely contrary when they interact face to face as some of them feel inferior and are not confident to give oral opinions openly. The strategy and approach of learning through FC can improve the feeling of enquisitiveness among students, therefore motivate them to pay better attention to the materials presented by the teachers.

The McGivney Burelle and Xue study (2013) found that what students learn in a classroom is proportional to their ability. Students do not feel they are forced to learn but given enough time to understand the lessons that teachers deliver. The learning atmosphere of FC also gives autonomy to students to make learning schedules. This scenario allows students to strengthen their competence as well as promote the development of intrinsic motivation. The table below shows a summary of researches done on FC by some researchers and its effects on student motivation. 
There have been some findings on the misconception of algebraic skills based on studies of the topics quadratic equation and quadratic functions. The study of Effandi et al. (2010) analyzes students> mistakes in learning the topic of qudratic equation which focuses on factoring subtopics, completion of squares and quadratic formula. Pongchawee et al.,(2006) wanted to study the trends and methods of students in solving more specific equations namely $x^{2}=K(K>0)$ and (X-a) (Xb) $=0$ ( $\mathrm{a}$ and $\mathrm{b}$ consists of real numbers) in three countries namely Thailand, Brunei Darussalam and the United States. Discovering the methods chosen by the students in finding the causes and solving the quadratic equation were the focus of the study. The findings of Effandi et al., (2010) reveal that most types of mistakes committed by students in using factorization are the types of errors in the transformation process and are followed by errors in the process of skills. The types of errors in the use of completion of squares are the errors in the process of skill, transformation, understanding and encoding. Similarly, in the use of quadratic formula method, there are errors in the process of skill, transformation, understanding and encoding. From the discussion, the researchers strongly feel that students had trouble understanding the needed terminology. This may be the results of lack of emphasis on terminology by teachers when teaching. Teachers should, therefore, ensure the teaching of mathematical concepts be balanced with arithmetic skills.

The findings of Pongchawee et al.,(2006) also support the discovery of the misunderstanding of concept in solving quadratic equations. The research shows majority of the students from the 3 countries surveyed do not know that equation, $\mathrm{x}^{2}=\mathrm{K}(\mathrm{K}>0)$ has two solutions. Students are not aware that the symbol $\langle\sqrt{ }\rangle$ means 〈positive square root) and in fact the equation, $x^{2}=9$ means ' $x$ ' is equal to $\pm \sqrt{9}$ ie \pm 3 . In addition, the interview results show that students have serious misconception problems because they do not know what their answer actually represents. Students are not sure whether $<\mathrm{x}$ ' written as ' $\mathrm{x}$ ' ' in the original equation represents $\mathrm{x}$ written as $x$ in the same equation. From a series of true or false questions it was found that one third of American students are confused about the concept of variables in the form of $(x-a)(x-b)=0$.

In conclusion, the students failed to provide what the questions asked them to do. They often write answers that are not in accordance with the concepts and methods they have learned. Although students can still get an almost accurate answer but they cannot explain what they are doing and why the answer is so. This is because they prefer to memorize the instrumental procedure than understanding the concepts. Students give answers without understanding every procedure they operate in. Students are also very concerned about the solution procedure without looking at the logic of the question. Mastery of skills of a topic should be grasped first by the students before the teacher moves to a new topic and asks students to use different methods. This will help increase the student>s conceptual understanding. 


\section{OBJECTIVES OF STUDY}

The study was conducted to achieve the following objectives:

a. To determine motivational differences between FC and conventional groups.

b. To determine significant differences between FC and conventional groups in terms of attention span.

c. To determine significant differences between FC and conventional groups in terms of level of confidence.

d. To determine significant differences between FC and conventional groups in terms of relevance.

e. To determine any significant differences between FC and conventional groups in terms of satisfaction.

\section{METHODOLOGY}

This non-equivalent control group design prepost test quasi-experimental study was carried out to review the effectiveness of FC learning applications in enhancing students' motivation. The algebraic components studied were quadratic equation and quadratic functions from form four Additional Mathematics syllabus. In this study, researchers used the existing classes (intact groups) as subjects of study based on the students' placement done by the school according to their academic achievement.

The population of the study was Form 4 students in 7 school Sekolah Menengah Kebangsaan Agama (SMKA) in Kelantan. The number of population studied was 1246 people consisting of 533 male students $(42.8 \%)$ and 713 female students $(57.2 \%)$. Though the population of the study was from a religious stream, the students were required to take the subject of Additional Mathematics. The sample of the study was not randomly selected from the population but instead they came from a group of existing classes. The samples consisted of two form 4 classes forming a total of 70 students from Bachok District. In this study, one class was made a treatment group and the other a control group. The assignment of treatment and control classes was determined by the school administrators after discussing with the Senior Mathematics and Science Teacher, Head of the Mathematics Panel and also the additional mathematics teacher in-charge. The treatment class consisted of 36 students; 19 boys and 17 female students where as the control class had 34 students consisting of 10 male students and 24 female students. Both classes were taught by the same teacher.

This study took about 9 weeks. During the course of the study, the treatment class was exposed to FC teaching and learning methods. The teaching and learning activities for the treatment class were divided into two parts, learning activities outside classroom and learning activities inside classroom. In the first part sessions the students were exposed to online teaching and learning via Edmodo application. In the second part, learning in the classroom, activities were more focused on the aspects of doing exercises, presentations, discussions within groups and teacher 
explanations if necessary. The control classroom on the other hand, was only exposed to conventional teaching and learning methods.

The research instrument was based on "Instructional Materials Motivation Survey" (IMMS) built by Keller (1987) based on the ARCS motivation model (attention, relevance, confidence, satisfaction). This instrument gives emphasis on the requirement that there must be motivation among students as well as providing a theoretical framework for the treatment in the study (Gabriel, 2005). This survey instrument has the right validity and reliability to be used in various forms of study. The complete contents of the questionnaire are as shown in Table 1.

Table 1 Additional Mathematical Motivation Questionnaire Content

\begin{tabular}{ccccc}
\hline Section & Aspects measured & No of item & Items & Source \\
\hline A & $\begin{array}{l}\text { Respondent } \\
\text { information }\end{array}$ & 4 items & $1-4$ & \\
\hline B & Motivation & 30 items & $1-30$ & IMC Model ARCS
\end{tabular}

Keller's (1987),

Song \& Keller (2001)

Gabrielle DM (2003)

Rosnani et al., (2010)

Kamariah et al.,(2010 a )

The attention aspect consists of 7 items, the relevant aspects 8 items, the aspect of confidence consists of 8 items and the satisfaction aspect contains 7 items. Students were given the choice of score 1 for strongly disagree, score 2 for disagree, score 3 for uncertain, score 4 for agree and score 5 for strongly agree.

\section{RESULT}

The mean score for the pre-test motivation variables does not show significant differences between the FC group and the conventional group. The mean score for the FC group is 102.32 (sd. 8.86) while the mean score for the conventional group is 104.21 ( $\mathrm{sd} \mathrm{8.13).} \mathrm{For} \mathrm{the} \mathrm{post} \mathrm{test,} \mathrm{the} \mathrm{mean} \mathrm{score} \mathrm{for} \mathrm{the} \mathrm{motivational} \mathrm{variable}$ for the FC group is 104.2 ( $\mathrm{sd}$. 3.79) which is higher than the conventional group of 64.44 (sd. 3.02). For motivational variables, data analysis for pre-test found the lowest score for motivation is 58 and the highest score is 112 based on 150 points. For post test, the lowest score for the motivational variable is 58 and the highest score is 112 based on 150 points. The overall mean for motivation is 84.76 
(sd. 19.86). ANOVA analysis was used to determine dependent variables associated with independent variables. The effect size of $\left(\mathrm{h}^{2}\right.$; partial eta squared) was also reported for each analysis. This study had a one-way ANOVA which is motivation. ANOVA's univariate analysis for motivation shows significant effect for $F(1,68)=$ 8.017, $\mathrm{p}<0.01, \mathrm{~h}^{2}=0.105$. Descriptive statistical analysis was carried out on four constructs of motivational variations namely attention, relevance, confidence and satisfaction. Table 4 shows the pre-test mean score for the motivational constructs.

The findings show the mean score for subscales attention, confidence and satisfaction is higher in FC group than the mean score of the conventional group. However, the mean score for the relevant subscale for the conventional group supersedes the relevant subscale mean score for the FC group. Descriptive statistics show the maximum score for the attention subscale is 34 and the minimum score is 8 (sd 8.81). For the relevant subscale the maximum score is 26 and the minimum score is 19 ( $\mathrm{sd} \mathrm{1.5).} \mathrm{Then} \mathrm{the} \mathrm{maximum} \mathrm{score} \mathrm{for} \mathrm{the} \mathrm{subscale} \mathrm{of} \mathrm{confidence} \mathrm{is} 29$ and the

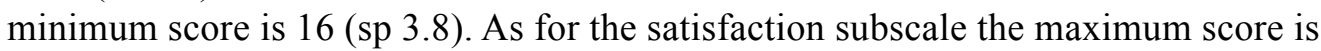
28 and the minimum score is 11 (sp 5.6). Descriptive statistical analysis found that the mean score for subscale attention and satisfaction for the FC group increased while the mean score for subscales relevant and confidence decreased. For the conventional group, descriptive statistics show that all mean scores for motivational subscales declined.

The ANOVA and multivariate MANOVA test results for motivational subscales which are attention, relevance, confidence and satisfaction. ANOVA's univariate test for motivation shows significant effect for $F(1,68)=8.017, p<0.01$, $\mathrm{h}^{2}=0.105$. Analysis multivariate MANOVA using correction Bonferroni for four tests $(\alpha==0.0125)$ was used to determine dependent variables that are related to independent variables. There are four one-way ANOVA tests. One each on attention, relevance, confidence and satisfaction. Wilk>s Lambda multivariate analysis test, $\left[\mathrm{F}(4,68)=822.28, \mathrm{p}<0.05, \eta^{2}=0.981\right]$ found that there was a major effect of independent variables on attention, relevance, confidence and satisfaction subscales.

ANOVA's univariate test for attention subscale shows a significant effect for learning group $\quad\left[\mathrm{F}(1,68)=986.54, \mathrm{p}<0.0125, \eta^{2}=0.937\right]$. There is a significant difference in the attention subscale for both learning groups. For the relevant subscale, the findings show that there is a significant effect on the method $[F(1,68)$ $\left.=11.31, \mathrm{p}<0.0125, \eta^{2}=0.146\right]$. The univariate analysis of confidence subscale shows that there is a significant effect on the $\left[\mathrm{F}(1,68)=1124.96, \mathrm{p}<0.0125, \eta^{2}=\right.$ 0.945 ] method. There is a significant difference in confidence subscale for both learning groups. For satisfaction subscale, univariate analysis shows that there is a significant effect with $\left[F(1,68)=1050.55, p<0.0125, \eta^{2}=0.941\right]$. This means there is a significant difference in satisfaction subscales for both learning groups. Based on the analysis, the impact size for subscales attention, confidence and satisfaction is large (Pallant, 2011) which contributes to over $90 \%$ in the subscale change. The impact size of the relevant subscale only contributes to $14.6 \%$ in relevant subscale changes. However, based on the Pallant Size Impact analysis (2011), it still has a great impact on the subscale change. 


\section{DISCUSSION}

Based on data analysis, the findings show that there are significant differences between FC and conventional groups in terms of motivation towards additional mathematics. Through further analysis, students in FC group differ from the conventional in terms of attentiveness, confidence, relevance and satisfaction. The effect size for motivation is large which is $\eta^{2}=0.981$. This shows a very significant effect from the treatment (Pallant, 2011).

The findings of this study support the findings of literature showing that the teaching and learning of FC can enhance students' motivation towards the subject studied (Chris Tisdell and Birgit Loch, 2017; Fabies, 2015; Kim et al., 2014; Galway et al., 2014; McLaughlin et al., 2014; and Greenberg and J. Zanetis, 2012). The researchers found that the learning methods of FC are able to enhance cooperation among students as well as to reduce their fear of the subject. Social relationships, which are the relationships that exist between individuals as they interact, have also improved. It can be seen from the aspects of behavior such as the way they communicate, their social skills, emotional aspects or feelings such as being compassionate, showing compromy, caring, offering mutual assistance and understanding of feelings of others.

This study displays there is high confidence within the students in the FC group. They demonstrated courage in expressing opinions during discussions in class and showed conviction in answering the questions posed by the teacher. This supports the research conducted by Fabies (2015), Kim et al., (2014) and McGivney -Burrelle and Xue (2013), who argue that active student engagement during a discussion session to cover issues creates excitement and increases their confidence level. Fun teaching and learning is very important for students with low learning motivation. McCollum et al.,(2017) suggests that the online teaching and learning as well as face to face using FC method is relevant to fulfill the requirements of 21 st century learning. This can meet the much needed '4Cs', namely communication, creativity, cooperation and critical thinking among students. The variety of methods used are relevant to the diversity of students' intelligence and interest and this stimulates students' participation to be more active and competitive.

According to Freeman et al.,(2014), the conventional teaching and learning method does not make it easy to describe the image as the image in the computer has visual and audio characteristics. The conventional teaching and learning method also makes it difficult for students to draw a graph and they might take a long time. Most students cannot describe the forms of graphs or geometries because they are abstract. This difficulty will negatively affect student motivation. Students will feel bored and disinterested in the subject.

Based on pre- and post tests, there is a decrease in the motivational scores of conventional group students. Based on motivation theory by Keller (1998), if there is a disturbance to the attention and interest of students arising either from the internal or external factors during the teaching and learning session, their level of 
motivation will decrease. To reduce the impact of such interruptions, teaching and learning methods and their materials must be interactive with user-friendly features. There should also be interaction space between materials used with students and teachers. McClelland (1978) states that motivation would be triggered if the goal to be achieved suits the environment and there is an active effort in achieving that goal. Conventional teaching and learning methods do not encourage active learning. Although there is a notion that traditional methods of teaching heighten the content of the lesson more but this method is criticized as it produces passive students and does not consider the different needs and ability of the students. Stereotypically, students are drilled with exercises alone in the classroom. Student interaction is not emphasized. Any difficulties raised to the teachers would only make the teacher scramble for time to help the many students in the classroom.

\section{CONCLUSION}

Based on this study, FC allows students to interact directly with the learning resources provided by teachers without contraints of time or place. Students can watch videos and materials uploaded by teachers repeatedly until they could understand the concept of algebra. Visuals during online teaching and learning sessions allow students to explore mathematical relationships and concepts which are difficult to explain through conventional teaching. The exploration aspect will increase students learning experiences and increase their motivation. The researchers' view is based on a study by Galway et al., (2014) which summarizes that through active teaching and learning strategies and discovery, students would actively engage during experiments using learning tools such as computers. The movement of their limbs and their senses will maintain the mood to learn and encourage them to continue to focus on the topics they are studying. Active student engagement during teaching and learning sessions creates a sense of excitement and increases their confidence level. Fun teaching and learning is very important for students with low learning motivation.

This study also found that FC method also serves as a teaching catalyst that can start and reduce the barriers of using technology in teaching and learning. Needless to say, there are a handful of students who have a negative attitude towards computer usage. The researchers feel by using computer hardware, the students experience of using computers will increase and erode the phobia and later motivate them to use the computer. Teachers and students are encouraged to use computer-assisted learning to facilitate the teaching and learning process as well as increasing the student's understanding of the concepts taught (Bernard, 2015). 


\section{REFERENCES}

Abeysekera, L., \& Dawson, P. (2015). Motivation and cognitive load in the flipped classroom: definition, rationale and a call for research. Higher Education Research and Development, 34 (1), 1-14.

Acar, Ö., Türkmen, L. \& Bilgin, A. (2015). Examination of Gender Differences on Cognitive and Motivational Factors that Influence 8thGraders> Science Achievement in Turkey, Eurasia Journal of Mathematics, Science \& Technology Education, 11 (5), 1027-1040.

Alessi, S and Trollip, S. (2001) Multimedia for Learning; Methods and develop ment. Third Edition Pearson Education. USA: 407-436

Asmawati Desa (2002). Psychology For Professional Groups. National University of Malaysia: McGraw-Hill (Malaysia) Sdn. Bhd.

Ayob, A. (2012). How to Increase Students' Interest in Science and Mathematics. Sultan Idris Education University.

Bergmann, J., and Sams, A. (2009). Remixing chemistry class: Two Colorado teachers make vodcast of their lectures to free up class time for hands-on activities. Learning and Leading with Technology, (December 2008), 22-27.

Bergmann, J. \& Sams, A. (2012). Flip Your Classroom: Reach Every Student in Every Class Every Day. Washington, DC: International Society for Technology in Education.

Bernard, JS (2015). The flipped classroom: fertile ground for nursing education research. International Journal of Nursing Education Scholarship, 12 (1), 99109.

Baker, W. (2000 ). The “Classroom Flip”: Using Web Course Management Tools Too Become The Guide By The Side.

Betihavas, V., Bridgman, H., Kornhaber, R., \& Cross, M. (2016). The evidence for 〈flipping out»: a systematic review of the flipped classroom in nursing education. Nurse Education Today, 38, 15-21.

Bixler, B. 2006. Motivation and its Relationship to the Design of Educational Games. Paper presented at the Summer Conf.

Cano, EM, Ruiz, JG \& Garcia, IA (2013). Integrating a Learning Constructionist Environment and the Instructional Design Approach into the Definition of a Basic Course for Em Embedded Systems Design. Computer Applications in Engineering Education, 23 (1), 36-53.

Chen, LL(2016). Impacts of flipped classroom in high school health education. Journal of Educational Technology Systems, 44 (4), 411-420.

Chris Tisdell \& Birgit Loch, 2017, How useful are closed captions for learning mathematics via online video ?, Journal of Mathematical Education in Science 2017 - Volume 48, 2017 - Issue 2.

Choi, SY ; L ee, H; and Yoo, Y . ( 2010 ) . «The Impact of Information Technology and Transactive Memory Systems on Knowledge Sharing, Application, and Team Performance: A Field Study,» MIS Quarterly, (34: 4) pp.855-870.

Chua, JSM, \& Lateef, FA (2014). The flipped classroom: viewpoints in Asian universities. Education in Medicine Journal, 6 (4), 20-26. 
Davies, RS, Dean, DL, \& Ball, N. (2013). Flipping the classroom and instructional . Integration in a College-Level Information Systems Spreadsheet Course. Education Technology Research and Development, 61, 563-580 .

DeLozier, SJ, \& Rhodes, MG (2016). Flipped classrooms: a review of key ideas and recommendations for practice. Educational Psychology Review, 1-11. http:// link.springer.com/article/10.1007/s10648-015-9356-9 .

Fatin Aliah Phang, Mohd Salleh Abu \& Mohammad Bilal Ali (2014). Contributing factors to the deterioration of students 'participation in the Science Stream: An Analysis of Thesis Highlights. eprints.utm.my/en/eprint/28550/1/19.pdf http:// eprints.utm.my/59753/1/fatinAliah2014 factorpleafmemoryresistence.pdf

Edy Hafizan Mohd Shahali, Lilia Halim, Mohamad Sattar Rasul, Kamisah Othman \& Mohd Afendi Zulkifeli. (2017). STEM Learning through Engineering Design: Impact on Middle Secondary Student>s Interest towards STEM. EURASIA Journal of Mathematics Science and Technology Education. ISSN: 1305-8223 (online) 1305-8215 (print) 201713 (5): 1189-1211DOI 10.12973/ eurasia.2017.00667a .

Effandi Zakaria, Ibrahim \& Siti Mistima. 2010. Analysis of Students' Error in Learning of. Quadratic Equations. Inter Ed Stud, 3 (3): 105-110

Engin, M. (2014). Extending the flipped classroom model: developing second language writing skills through studentcreated digital videos. Journal of the Scholarship of Teaching and Learning, 14 (5), 12-26.

Fabris (2015). Videos Find Their Place In and Out of the Classroom.Chronicle of Higher Education. 17 March 2015.Retrieved from http://chronicle.com/blogs/ wiredcampus/videosfind-their-place-in-and-out-of-the classroom / 56113 Cid = wc \& utm_source $=$ wc \& utm_medium $=$ en .

Freeman, S., Eddy, S., McDonough, M., Smith, M., Okoroafor, N., Jordt, H., \& Wenderoth, M. (2014). Active learning increases student performance in science, engineering, and mathematics. Proceedings of the National Academy of Sciences of the United States of America, 111 (23), 8410-8415. http://doi.org/10.1073/ pnas.1319030111

Gabrielle, D. NM. (2005). The effects of technology-mediated instructional strategies on motivation, performance and self-directed learning. Doctor dissertation, Florida State University .

Galway, LP ., Corbett , KK, Takaro, TT . ,, Tairyan, K . , and Frank, E. (2014). A novel integration of online and flipped classroom instructional models in public health higher education. BMC Medical Education 2014, 14: 181 http://www. biomedcentral.com/1472-6920/14/181.

Greenberg AD , \& Zanetis, MA (2012). "The impact of broadcast and streaming video in education, «Ainhouse Research, CISCO, 2012.

Huang, YN, \& Hong, ZR (2016). The effects of a flipped English classroom intervention on students' information and communication technology and English reading comprehension. Educational Technology Research and Development, 64 (2), 175-193.

Jackson, SL 2003. Research methods ad statistics: A critical thinking approach. USA: Wadsworth / Thomson Learning 
Jensen, JL, Kummer, TA, \& Godoy, PDDM (2015). Improvements from a flipped classroom may simply be the fruits of active learning. CBE-Life Sciences Education, 14 (1), article 5.

Jones, K., Lavicza, Z., Hohenwarter, M., Lu, A., Dawes, M., Parish, A. and Borcherds, M. 2009. Establishing a professional development network to support teachers using dynamic mathematicssoftware GeoGebra. Proceedings of the British Society for Research into Learning Mathematics, 29 (1), 97-102.

Kamariah Abu Bakar, Rohani Ahmad Ahmad Tarmizi, Rahil Mahyuddin, Habibah Elias, Wong Su Luan, Ahmad Fauzi Mohd Ayub. 2010a. Relationship between university student's achievement motivation, attitude and academic performance in Malaysia. Procedia Social and Behavioral Science 2 (2010). pp 4906-4910

Kamariah Abu Bakar, Ahmad Fauzi Mohd Ayub, Rohani Ahmad Tarmizi .2010b. Utilization of Computer Technology in Learning Transformation. International Journal Of education and Information Technologies .2 (4). : 91-99

Malaysia Education Ministry. (2003). Integrated High School Curriculum: Descriptions of Form Mathematics Additional Mathematics Form IV. Curriculum Development Center, Ministry of Education, Malaysia. Kuala Lumpur: Dewan Bahasa dan Pustaka.

Malaysia Education Ministry. (2013). Malaysian Education Development Plan (2013-2025).

Katz \& Barton, VJ, \& Barton, B. (2007). Stages in the history of algebra with implications for teaching. Educational Studies in Mathematics, 66 (2), 185-201.

Keller, JM 1987. Strategies for stimulating the motivation to learn. Performance and Instruction, 26 (9): 1-8.

Kim, MK, Kim, SM, Khera, O., \& Getman, J. (2014). The experience of three flipped classrooms in an urban university: an exploration of design principles. Internet \& Higher Education, 2 2, 37-50.

Knowles, M. (1984). The Adult Learner: A Neglected Species (3rd Ed.). Houston, TX: Gulf Publishing.

Kong, SC (2014). Developing information literacy and critical thinking skills through domain knowledge learning in digital classrooms: an experience of practicing flipped classroom strategy. Computers \& Education, 78, 160-173.

Lage, MJ, Platt, GJ, Treglia, M., and Lage, J. (2000). Inverting the Classroom: A Gateway to Creating an Inclusive Learning Environment, 31 (1), 30-43.

Lancaster \& Stillman (2003). When Generations Collide: Who They Are. Why They Clash. How to Solve The Generational Puzzle at Work. Harper Collins.

Lowell, J., Utah, B., Verleger, MA, and Beach, D. (2013). The Flipped Classroom: A Survey of the Research.

Lima, RN and Tall, D. (2006). The concept of equation: what have students met before? Proceedings of the 30th Conference of the International Group for the Psychology of Mathematics Education, Prague, Czech Republic, vol. 4, 233-241. 
Maushak, N., Lincecum, L. \& Martin, L. (2000). Using the Internet to Promote Technology Integration, Higher-order Thinking Skills and Motivation. In D. Willis, J. Price \& J. Willis (Eds.), Proceedings of SITE 2000 - Society for Information Technology \& Teacher Education International Conference (pp. 1499-1504). Chesapeake, VA: Association for the Advancement of Computing in Education (AACE). Retrieved May 8, 2018 from https://www.learntechlib. org/primary/p/15857/.

Mc Laughlin JE , Roth MT, Glatt DM , Gharkholonarehe N, Davidson CA, Griffin LM , Esserman DA, Mumper RJ . (2014). The Flipped Classroom: A Course Redesign To Foster Learning And Engagement In A Health Professions School. Academic Medicine 89 (2): 236-243, FEB 2014 DO I: 10.1097 / ACM .0000000000000086

Mazur, AD, Brown, B., \& Jacobsen, M. (2015). Learning designs using flipped classroom instruction. Canadian Journal of Learning and Technology, 41 (2), $1-26$.

McCollum, BM, Fleming, CL, Plotnikoff, KM, \& Skagen, DN (2017). Relationships in the Flipped Classroom. The Canadian Journal for the Scholarship of Teaching and Learning, 8 (3). https://doi.org/10.5206/cjsotl-rcacea.2017.3.8

Mc Clelland DC , (1978). Managing motivation to expand human freedom. American Psychologist 33 (3): 201-210 · DOI: 10.1037 / 0003 066X.33.3.201.https://www. researchgate.net/publication/232577028_Managing_motivation_to_expand human freedom .

McGivney-Burelle, J., \& Xue, F. (2013). Flipping calculus. PRIMUS, 23 (5), 477486.

Naime-Diefenbach, B. (1991). Validation of attention and confidence as independent components of the ARCS motivational model. Unpublished doctoral dissertation, Florida State University, Tallahassee. http:/www.aect.org/pdf/ proccedings/2006/06_12.pdf [20/8/2017].

O〉Flaherty, J., \& Phillips, C. (2015). The use of flipped classrooms in higher education: a scoping review. The Internet and Higher Education, 25, 85-95.

Pallant.J. (2011). SPSS survival manual: a step by step guide to data analysis using SPSS . Sydney: Ligare Book Printer

Paul R. (2013), Understanding The Various Generations - Their Philosophies And Characteristics of Working Papers Presented In The Millenials Seminar : Gen. Y \& Z: The New Workforce And The Challeges 21 \& 22 October 2013 Putra World Trade Center Kuala Lumpur -http: //globaleventasia.com/event.

Presti, CR (2016). The flipped learning approach in nursing education: a literature review. Journal of Nursing Education, 55 (5), 252-257.

Pongchawee, V. , Nerida FE, \& Clements MA ,. (2006). Student's Attempt to Solve Two Elementary Quadratic Equations: A Study in Three Nation. University of Chiang Mai, University of Illinois.

Rosnaini Mahmud, Mohd Arif Ismail, Lim Ai Kiew. ( 2010. ) Development and Evaluation of a CAI Courseware "G-Reflect" on Student's Achievement and Motivation in Learning Mathemati cs. European Journal of Social Science, 8 (4): 557-568. 
Shahhanim Yahya (2012) Between Generation Gaps. FACT www.ippbm.gov.my Issue 1- 2012. Uploaded on March 10, 2015.

Siegle, D. (2013). Differentiating Instruction by Flipping the Classroom, 37 (1), 51 56.doi: 10.1177 / 1076217513497579.

Song, SH 1998. The effects of motivationally adaptive computer-assisted instruction developed through the ARCS model in Song SH \& Keller JM 2001. Effectiveness of Motivationally Adaptive Computer-Assisted Instruction on the Dynamic Aspects of Motivation. ETR \& D, Vol. 49, no. 2.2001, pp. 5-22! SSN10: 42- 629.

Song SH \& Keller JM 2001. Effectiveness of Motivationally Adaptive ComputerAssisted Instruction on the Dynamic Aspects of Motivation. ETR \& D, Vol. 49, no. 2.2001, pp. 5-22! SSN10: 42- 629.

Suzuki, K \& Keller, J, (2004), Learner motivation and e-learning design: A multinationally validated process, Journal of Educational Media, Vol 29, No 3, Page (s) 229-239.

Strayer, JF (2012). How learning in an inverted classroom influences cooperation, innovation and task orientation. Learning Environments Research, 15 (2), 171 193.doi: 10.1007 / s10984-012-9108-4

Taspcott, Don (2008). Grown Up Digital: How the Net Generation is Changing Your World. McGraw-Hill.

Ogden, L \& Pyzdrowski, LJ \& Shambaugh, Neal. (2014). A teaching model for the college algebra flipped classroom. 47-70. 10.4018 / 978-1-4666-4987-3.ch003.

Piaget, J., \& Cook, MT (1952). The origins of intelligence in children. New York, NY: International University Press dlm Mayer, RE (2014). The Cambridge handbook of multimedia learning. New York: Cambridge University Press.

Visser, J., and Keller, JM "The Clinical Use of Motivational Messages: An Inquiry into the Validity of the ARCS Model of Motivational Design." Instructional Science, 1990, 19, 467-500

Vygotsky, LS (1987). Thinking and speech. In RW Rieber \& AS Carton (Eds.), The collected works of LS Vygotsky, Volume 1: Problems of general psychology (pp. 39-285). New York: Plenum Press. 